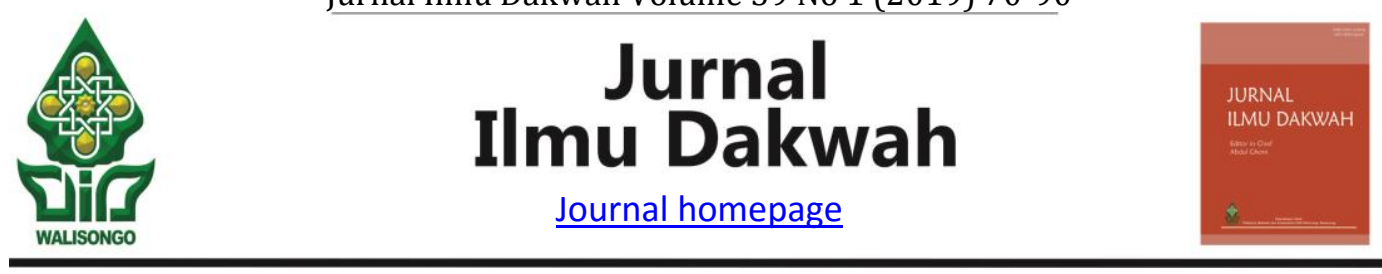

\title{
Penerapan Cognitive Behaviour Therapy dalam Mengembangkan Kepribadian Remaja di Panti Asuhan
}

\author{
Dewi Khurun Aini \\ Fakultas Psikologi dan Kesehatan, UIN Walisongo Semarang \\ Email: dewizahwa01@gmail.com
}

\begin{abstract}
ABSTRAK
This study aims to determine the process and response to the implementation of the "Positive Brain and Psychological Approach (CBT)" in developing the personality of young women who are in the Aisyiyah orphanage Ronggowarsito Semarang. This study involved 30 female respondents of Aisyiyah Orphanage as research subjects. The research methodology in this study is participatory action research. This methodology is one of the research models that looks for something to link the research process to the process of social change. Social change in question is how in the process of empowerment can realize three benchmarks, namely the existence of joint commitment with the community and the existence of new institutions in the community that are built based on needs. Meanwhile, for the results in this study using a qualitative approach to data analysis, the collected data is made in a matrix, this analysis is called interactive analysis. In the matrix, descriptive fragments of data will be presented around certain community events or experiences. The stages of the analysis are in the form of data collection (data collection), data reduction (data reduction), data presentation (data display), drawing conclusions (conclutions). The results showed the personality development program of young women who are in orphanages with the Cognitive Behavior Therapy approach can improve cognitive abilities and behaviors of research subjects. Research subjects do social interaction well, so that research subjects while maintaining relationships or social contact, so that research subjects feel not alone. The personality of the orphanage girls increasingly develops for the better.
\end{abstract}

Penelitian ini bertujuan untuk mengetahui proses dan respon pelaksanaan "Pendekatan Brainology dan Psikologi Positif (CBT)" dalam mengembangkan kepribadian remaja putri yang berada di panti asuhan Aisyiyah Ronggowarsito Semarang. Penelitian ini melibatkan 30 responden remaja putri Panti Asuhan Aisyiyah sebagai subjek penelitian. Metodologi penelitian pada kajian ini adalah participatory action research. Metodologi ini merupakan salah satu model penelitian yang mencari sesuatu untuk menghubungkan proses penelitian ke dalam proses 
perubahan sosial. Perubahan sosial yang dimaksud adalah bagaimana dalam proses pemberdayaan dapat mewujudkan tiga tolak ukur, yakni adanya komitmen bersama dengan masyarakat dan adanya institusi baru dalam masyarakat yang dibangun berdasarkan kebutuhan. Sementara, untuk hasil dalam penelitian ini menggunakan pendekatan kualitatif dengan analisis data, data yang sudah terkumpul dibuat dalam matriks, analisisi ini disebut analisis interaktif. Dalam matriks akan disajikan penggalan-penggalan data deskriptif sekitar peristiwa atau pengalaman masyarakat tertentu. Tahapan-tahapan analisisnya berupa pengumpulan data (data collection), reduksi data (data reduction), penyajian data (data display), penarikan kesimpulan (conclutions). Hasil penelitian menunjukkan Program pengembangan kepribadian remaja putri yang berada di panti asuhan dengan pendekatan Cognitive Behaviour Therapy dapat meningkatkan kemampuan kognitif dan perilaku subjek penelitian. Subjek penelitian melakukan interaksi sosial dengan baik, sehingga subjek penelitian tetap menjaga hubungan atau kontak sosial, sehingga subjek penelitian merasa tidak sendiri. Kepribadian remaja putri panti semakin berkembang menjadi lebih baik.

Kata kunci: Cognitive Behaviour Therapy, Kepribadian, Remaja, Panti Asuhan.

\section{Pendahuluan}

Permasalahan kompleks yang dihadapi generasi muda seiring perkembangan teknologi dan keterbukaan informasi seperti penyebaran narkoba, HIV/Aids, pergaulan bebas dan lain lain semakin marak terjadi. Di samping kemajuan teknologi akibat adanya era globalisasi, dapat dilihat pula arus kemorosotan akhlak yang semakin melanda di kalangan sebagian pemuda. Dalam berbagai berita sering ditemukan berbagai kasus tentang tawuran pelajar, penyebaran narkoba, kenakalan remaja, kriminalitas, kemerosotan moral, minuman keras, pencurian yang dilakukan oleh anak-anak yang berusia belasan tahun, meningkatnya kasus-kasus kehamilan di kalangan remaja putri pra nikah dan beberapa kasus lainnya. Kemerosotan moral yang terjadi menuntut untuk memberikan solusi terbaik agar generasi-generasi bangsa bisa terhindarkan dari semakin rusaknya moral akhlak masa kini.

Proses perkembangan perilaku dan pribadi remaja dipengaruhi oleh tiga faktor dominan, yaitu faktor bawaan (heredity), kematangan (maturation), dan lingkungan (environment). Ketiga faktor tersebut mungkin dapat menguntungkan atau menghambat atau membatasi laju proses perkembangan. Beberapa diantaranya; masalah yang timbul berkaitan dengan perkembangan fisik dan psikomotorik, masalah yang timbul berkaitan dengan perkembangan bahasa dan perilaku kognitif, masalah yang timbul berkaitan dengan pekembangan perilaku sosial, moralitas dan keagamaan. Masalah yang timbul berkaitan dengan perilaku afektif, konatif dan kepribadian, misalnya mudah dipengaruhi untuk melampiaskan ketegangan emosionalnya meskipun tidak tahu maksudnya, ketidakmampuan menegakkan kata hatinya membawa akibat sukar terintegrasi dan sintesis fungsi-fungsi psikofisiknya. Pada masa remaja terjadi perubahan baik fisik maupun psikis yang menyebabkan remaja dalam kondisi rawan pada proses pertumbuhan dan perkembangannya. Pada masa ini merupakan masa terjadinya proses awal pematangan organ reproduksi dan perubahan hormonal yang nyata. Permasalahan remaja juga merupakan permasalahan yang sangat kompleks, mulai permasalahan TRIAD KRR (tiga resiko yang dihadapi oleh remaja, yaitu Seksualitas, HIV/AIDS dan Napza) serta Kesehatan Reproduksi Remaja.

Inilah yang menggugah peneliti untuk mengangkat tema penelitian tentang pengembangan kepribadian remaja putri di panti asuhan. Remaja di panti asuhan merupakan salah satu contoh remaja yang secara sosial kurang beruntung, sehingga 
kemungkinan terjadinya kenakalan remaja mungkin saja terjadi, karena secara kondisi keluarga yang tidak lengkap. Menurut (Departemen Sosial, 2016); secara konseptual panti asuhan anak adalah suatu lembaga usaha kesejahteraan sosial yang mempunyai tanggung jawab untuk memberikan pelayanan kesejahteraan sosial pada anak terlantar dengan melaksanakan penyantunan dan pengentasan anak terlantar, memberikan pelayanan pengganti orang tua/wali anak dalam memenuhi kebutuhan fisik, mental dan sosial kepada anak asuh sehingga memperoleh kesempatan yang luas, tepat dan memadai bagi pengembangan kepribadianya sesuai dengan yang diharapkan sebagai bagian dari generasi penerus cita-cita bangsa dan sebagai insan yang akan turut serta aktif dalam bidang pembangunan nasional. Pada umumnya, panti asuhan di kota-kota besar berusaha mengatasi permasalahan-permasalahan sosial yang terjadi pada anak dimana panti asuhan tersebut menampung anak-anak yang mengalami berbagai permasalahan (Muchti, 2000). Maka kegiatan penelitian ini berupaya untuk mewujudkan perkembangan remaja di Panti Asuhan dengan optimal seperti remaja lainnya dan dapat membantu permasalahan yang dialami remaja.

Kegiatan Penelitian ini difokuskan pada remaja penghuni Panti Asuhan Aisyiyah 2 Ronggowarsito, Semarang dengan isu Penelitian dan Pengembangan Kepribadian Remaja melalui Pendekatan Brainology dan Psikologi Positif (Training, Konseling, Praktek, dan Evaluasi program) yang diwujudkan dengan CBT (Cognitive Behavior Theraphy). Brainology adalah Pembelajaran berbasis pada otak, sedangkan pendekatan psikologi positif berhubungan dengan penggalian emosi positif, seperti bahagia, kebaikan, humor, cinta, optimis, baik hati, dan sebagainya. (Shoshani, Steinmetz, \& dan Kanat-Maymon, 2016) melakukan penelitian dengan menerapkan program psikologi positif Maytiv pada 2517 orang siswa kelas 7-9 di sekolah menengah di pusat kota Israel. Hasilnya, para siswa yang diberikan intervensi psikologi positif menunjukkan peningkatan dalam kesejahteraan emosional (emotional subjective well-being), hubungan dengan teman sebaya, keterhubungan emosional, keterhubungan kognitif, dan prestasi akademik. Psikologi positif tidak bermaksud mengganti atau menghilangkan penderitaan, kelemahan atau gangguan (jiwa), akan tetapi lebih kepada menambah khasanah atau memperkaya, serta untuk memahami secara ilmiah tentang pengalaman manusia.

Pemilihan Panti Asuhan Aisyiyah 2 sebagai lokus penelitian, didasarkan beberapa alasan, yaitu: (1) Secara geografis panti ini berada di wilayah pinggiran kota dengan lingkungan hunian berupa perumahan dengan berbagai individual deferences penghuninya, sehingga menarik untuk diamati dan dilakukan proses penelitian (2) Bentuk panti ini menarik karena sebagai lembaga sosial, panti ini berbasis komunitas (3) Sebagai bahan pertimbangan adalah bahwa panti ini dikhususkan bagi anak dan remaja perempuan dari kalangan yatim piatu dan dhuafa. Kegiatan penelitian dilakukan pada remaja putri penghuni panti asuhan dengan isu pengembangan kepribadian menggunakan pendekatan brainology dan psikologi positif (CBT) yang ditunjukkan dengan training disertai praktek dan latihan, konseling, kegiatan sosialisasi (pembuatan poster), dan evaluasi program untuk memastikan pelaksanaan program lanjutan.

Dengan argumentasi tersebut yaitu banyaknya problematika TRIAD KRR, kekerasan pada remaja, bullying, kecemasan, sehingga dipandang perlu akan kebutuhan pendidikan, pembinaan yang dapat membantu remaja, keinginan akademisi untuk membentuk program penelitian melaui pendekatan terapi 'cognitive behaviour' remaja dengan membuat isu penelitian sustainable serta kesesuaian dengan kondisi remaja putri di Panti Asuhan menjadi alasan bagi peneliti untuk memilih subyek penelitian yang sangat sesuai dengan judul penelitian ini. Proses pemberian terapi CBT untuk mengembangkan kepribadian 'positif bagi remaja (anak panti)' dengan cara pembinaan anak panti dan pemberian ketrampilan 'konseiling 
dan pendampingan' bagi pengasuh atau pengurus panti, sehingga diharapkan kepribadian anak panti menjadi lebih baik.

Penelitian-penelitian yang memiliki keterkaitan dengan penelitian yang sedang dikaji diantaranya (Hartanti, 2008), melakukan penelitian tentang "Pengaruh Mindset terhadap Hasil Belajar Kimia Siswa Kelas XI IPA Madrasah Aliyah Negeri 1 Semarang", ada pengaruh positif antara mindset dan hasil belajar kimia siswa kelas XI IPA Madrasah Aliyah Negeri 1 Semarang, ditunjukan oleh koefisien korelasi rxy $=0,807$ pada taraf signifikan $\alpha=0,01$ dan koefisien determinasi $r 2=0,651$. Hal ini menunjukkan bahwa 65,1\% variasi skor hasil belajar kimia siswa ditentukan oleh intensitas mindset melalui fungsi tafsiran $Y^{\wedge}=0,729 \mathrm{X}+15,974$. (Rifai, 2015), "Penyesuaian Diri pada Remaja yang Tinggal di Panti Asuhan (Studi Kasus Remaja yang tinggal di Panti Asuhan Yatim Piatu Muhammadiyah Klaten)", Hasil dari penelitian tersebut menunjukkan bahwa Remaja Panti Asuhan Yatim Piatu Muhammadiyah Klaten secara garis besar memiliki penyesuaian diri yang baik, walau pada awalnya remaja panti asuhan mengalami perasaan takut dan cemas ketika pertama kali berada di dalam panti asuhan akan tetapi remaja panti asuhan mengatasi hal tersebut dengan mengikuti segala bentuk aktivitas dan kegiatan yang berlangsung secara bersamasama dan pada akhirnya remaja panti asuhan dapat menyesuaikan diri dengan baik serta menerima keadaanya yang sekarang. Remaja panti asuhan muhammadiyah klaten mampu mengatasi sebuah masalah dengan tenang dan dapat menyelesaikanya dengan musyawarah secara bersama-sama. Faktor utama yang mempengaruhi penyesuaian diri remaja panti adalah lingkungan dan kondisi panti asuhan, seperti tidak ada kelompok senior maupun junior sehingga tidak menghambat proses penyesuaian diri remaja panti asuhan. Kemudian kendala yang dihadapi remaja panti asuhan adalah sikap pengasuh yang terkadang memiliki sifat yang sangat keras sehingga membuat remaja panti asuhan menjadi takut.

Berdasarkan penelitian, (Anggraeni, H.T, 2014) yang berjudul: Pembentukan Kepribadian Muslim Di Panti Asuhan Putri Darul Hadlonah Purwokerto, Hasil penelitian tersebut menunjukkan bahwa Panti asuhan sebagai lingkungan utama anak asuh dimana nantinya mereka akan diberi pendidikan yang layak baik di sekolah, di masyarakat juga di dalam panti itu sendiri. Semua itu demi terwujudnya pembentukan kepribadian muslim bagi anak asuhnya, itu dibuktikan dengan pembiasaan yang baik, pemberian ketedanan yang baik, juga dengan nasihat yang tak pernah terlupakan di setiap harinya baik berupa sanjungan, motivasi ataupun teguran.

Berdasarkan Setyaningsih, (2013) "Peran Panti Sosial Petirahan Anak (PSPA) Satria Baturaden dalam Pembentukan Kepribadian Anak". Hasil penelitian menunjukan bahwa: Peran Panti Sosial Petirahan Anak (PSPA) Satria Baturaden dalam pembentukan kepribadian anak cukup baik dengan memberikan bimbinganbimbingan kepada anak-anak yang bermasalah sehingga anak dapat mengembangkan kepribadiannya menjadi anak yang mandiri, percaya diri, bertanggung jawab dan disiplin. Hambatan yang dihadapi oleh PSPA Satria Baturaden dalam pembentukan kepribadian anak yaitu: (1) perkembangan anak berbeda, (2) sifat tertutup, (3) Pelayanan petirahan anak berlangsung singkat hanya kurang lebih 1 bulan, (4) sarana dan prasarana yang kurang memadai. Upaya untuk mengatasi hambatan-hambatan tersebut yaitu (1) melakukan pendekatan dengan anak meggunakan metode kasih sayang agar anak dapat membuka dirinya kepada orang lain, (2) tidak menyeragamkan semua anak dalam pemberian bimbingan, (3) memberikan follow up kepada orang tua dalam rangka memberikan penguatan positif kepada anak, dan (4) melengkapi sarana dan prasarana yang belum ada dengan mengalokasikan dana PSPA. Keberhasilan peran Panti Sosial Petirahan Anak Satria Baturaden dalam pembentukan kepribadian anak memang belum berjalan lancar, 
tapi bermanfaat bagi anak agar dapat menerapkannya dalam kehidupan seharihari.Selama di Panti Sosial Petirahan Anak (PSPA) Satria Baturaden anak menunjukan sikap disiplin, mandiri, percaya diri dan bertanggung jawab.

Suratmi, (2008), melakukan penelitian tentang "Hubungan Peran Pengasuh dan Keterpenuhan Kebutuhan Aspek-aspek Perkembangan Pribadi yang Integral Anakanak Asuh di Panti Asuhan Pondok El-Jireh Yogyakarta". Hasil dari penelitian tersebut menunjukkan bahwa ada hubungan yang positif antara peran pengasuh dan keterpenuhan kebutuhan pada aspek-aspek perkembangan pribadi yang integral para anak asuh di panti Asuhan Pondok El-Jireh Yogyakarta.

Mirza, (2013), melakukan penelitian tentang "Cognitive Behavior Therapy untuk meningkatkan Regulasi Emosi pada Anak Korban Konflik Aceh". Hasil yang diperoleh menunjukkan adanya peningkatan kemampuan regulasi emosi subjek penelitian. Maryati, (2015) melakukan penelitian "Pengaruh Terapi Kognitif Perilaku terhadap Perilaku Asertif pada Remaja". Hasil penelitian ini menunjukkan bahwa ada pengaruh pelatihan terapi kognitif untuk meningkatkan perilaku asertif pada remaja. Remaja yang mendapat treatmen terapi kognitif perilaku memiliki perilaku asertif lebih tunggi daripada remaja yang tidak mendapat treatmen.

Della, (2012) melakukan penelitian "Cognitive Behavior Therapy untuk Meningkatkan Self Esteem pada Mahasiswa Universitas Indonesia yang mengalami Distres Psikologis." Hasil penelitian menunjukkan bahwa intervensi ini efektif meningkatkan self esteem pada mahasiswa yang mengalami distres psikologis, yang ditunjukkan dengan peningkatan skor self esteem dan penurunan emosi negatif dan perubahan perilaku dengan mengurangi perilaku menghindar. Iswara, (2013), melakukan penelitian "Penerapan Konseling Kognitif Perilaku untuk Meningkatkan Kemampuan Penyesuaian Diri pada siswa Kelas X SMA Negeri 1 Patianrowo" . Hasil penelitian menunjukkan bahwa konseling kognitif perilaku efektif dalam meningkatkan penyesuaian diri siswa di sekolah pada siswa kelas X SMA Negeri 1 Patianrowo Kab. Nganjuk. Nurodin, (2017) melakukan penelitian tentang "Pendekatan Cognitive Behavioran Therapy (CBT) dalam Mereduksi Kecemasan Menghadapi Dunia Kerja Penyandang Tunadaksa". Hasil penelitian menunjukkan bahwa penerapan pendekatan Cognitive Behavioral Therapy (CBT) penyandang tunadaksa dapat mereduksi kecemasan menghadapi dunia kerja yang dialami.

\section{Metode}

Strategi penelitian yang digunakan dalam kajian ini adalah Action Research. Metode Action Research merupakan salah satu model penelitian yang mencari sesuatu untuk menghubungkan proses penelitian ke dalam proses perubahan sosial. Perubahan sosial yang dimaksud adalah bagaimana dalam proses pemberdayaan dapat mewujudkan tiga tolak ukur, yakni adanya komitmen bersama dengan masyarakat dan adanya institusi baru dalam masyarakat yang dibangun berdasarkan kebutuhan. Penelitian ini membawa proses penelitian dalam lingkaran kepentingan orang dan menemukan solusi praktis bagi masalah bersama dan isu-isu terhadap masalah yang dihadapi remaja yang berada di panti.

\section{a. Brainology (Growth Mindset) yang diwujudkan dalam CBT (Cognitive Behavior Theraphy)}

Brainology (growth mindset) tidak asing lagi dengan penulis yang bernama Carol S. Dweck dalam dunia psikologi. Tokoh tersebut mengkategorikan dua tipe orang ditinjau dari cara berfikir yaitu growth mindset dan fixed mindset. Growth mindset yang akan dibahas adalah tipikal orang yang tidak pernah menyerah. Mereka yang berada dalam kategori ini cenederung berfikir positif tentang kemampuan mereka dan mampu memperbaiki diri dengan melihat sisi kelemahannya dalam segala hal. 
Seseorang dengan cara berfikir growth mindset percaya bahwa kemampuan seseorang terletak pada kedinamisan dan keyakinan diperbaiki dengan usaha yang baik. Sebagai contoh, mereka yang tergolong dalam growth mindset ketika mengalami kegagalan akan kembali mencoba dan belajar dari kesalahan atas kegagalannya. Motivasi mereka akan muncul karena tingkat kepercayaan akan kemampuan mereka selalu mengarah ke sisi positif.

Disisi lain, fixed mindset adalah tipikal orang yang mudah menyerah dan condong menyalahkan kelemahan dalam diri mereka. Orang-orang yang selalu melihat sisi negatif dalam diri mereka dan menganggap kegagalan sebagai akhir dari segalanya. Mereka yang tergolong dalam fixed mindset condong berfikir negatif jika mengalami kegagalan dalam segala hal dan mudah putus asa atau tidak mau mencuba kembali serta menyalahkan takdir. Tanggap pada perubahan adalah sesuatu yang akan sangat berpengaruh pada keberhasilan seseorang. Hidup adalah sesuatu yang nyata yang akan menjadi baik jika dijalani dengan usaha terus menerus.

Growth berarti perkembangan atau pertumbuhan dan Mindset merupakan bagian penting dari kepribadian dan di dalam buku "The Secret of Mindset", Adi W Gunawan mengutip dari kamus elektronika menyebutkan mind-set terdiri dari dua kata: mind dan set. Kata "mind" berarti "sumber pikiran dan memori; pusat kesadaran yang menghasilkan pikiran, perasaan, ide, persepsi yang menyimpan pengetahuan dan memori". Kata "Set" berarti "mendahulukan peningkatan kemampuan dalam sesuatu kegiatan, keadaan utuh/solid".

Mindset adalah kepercayaan-kepercayaan yang mempengaruhi sikap seseorang; sekumpulan kepercayaan, keyakinan atau suatu cara berpikir yang menentukan perilaku dan pandangan, sikap, dan masa depan. Sikap mental tertentu atau watak yang menentukan respons dan pemaknaan seseorang terhadap situasi. Jadi, mindset sebenarnya kepercayaan (belief), atau sekumpulan kepercayaan (set of beliefs), atau cara berpikir yang mempengaruhi perilaku dan sikap seseorang. Pemikiran yang mendalam sehingga mencapai level yang disebut dengan keyakinan. Mindset ini dibentuk dari apa yang masuk ke dalam diri kita selama bertahun-tahun.

Mindset juga diartikan sebagai sebuah cara berpikir dan kepercayaan seseorang yang mempengaruhi setiap sikap dan perilaku seseorang yang pada akhirnya menentukan masa depan dan level keberhasilan hidup seseorang. Banyak sekali yang dapat mempengaruhi terbentuknya mindset. Banyak faktor yang dapat mempengaruhi terbentuknya mindset. Seperti faktor pendidikan dan pengalaman. Kenyataannya, kemampuan tertentu dapat dipelajari dan bahwa tugas tertentu akan memberi mereka kesempatan untuk belajar.

Salah satu cara paling efektif untuk menunjukkan kepada siswa bagaimana menerapkan pola pikir berorientasi pertumbuhan adalah untuk menjelaskan kepada siswa bahwa otak 'lunak'. Ini berarti bahwa otak berubah dan 'tumbuh' sesuai dengan cara penggunaannya, (Dahlia, 2010). Beberapa cara mengajarkan brainology kepada siswa adalah:

a. Seorang individu memiliki sel-sel di otak individu, disebut neuron, "berkomunikasi" atau "berbicara" satu sama lain.

b. Begitu individu tersebut memiliki pemikiran untuk pertama kalinya, ada kemungkinan lebih baik bahwa sel-sel itu 'saling berbicara' untuk kedua kalinya, dan individu akan memikirkan hal yang sama lagi.

c. Begitu proses terjadi cukup lama di otak, otak akan berinvestasi di jaringan atau jalur itu dengan menambahkan lemak putih yang disebut myeline untuk membantu sinyal bergerak lebih cepat di antara jaringan.

d. Proses ini sangat penting untuk pembelajaran, juga dimana banyak tantangan individu terjadi karena ini juga dimana kepercayaan terbentuk. Karena individu 
berada di lingkungan yang sama, dengan orang yang sama, secara umum, berulang-ulang, individu akan mendapat umpan balik serupa yang serupa '- yang mungkin membawa individu untuk memiliki thoghts serupa berulang kali.

e. Sama seperti otak berinvestasi pada jalur tertentu yang dilihatnya 'banyak digunakan', ia juga akan menghilangkan energi dan jalur saya dari jalur yang sama jika jaringan pesaing lainnya diaktifkan lebih sering. (prinsip "menggunakannya atau hilang").

Dari pendapat tersebut, maka perlunya pemberian dari pengembangan pikiran tentang apa yang manusia lihat dengan sesuatu yang lebih positif dan satu hal yang pada umumnya dalam kehidupan seorang individu pasti banyak halangan dan cobaan yang harus kuat dan tegar dalam menjalani untuk mencapai kesuksesan. Harapan dari penelitian ini dapat membantu individu untuk berubah menjadi pribadi yang lebih baik.

\section{b. Psikologi Positif}

Martin E. P Seligman, seorang professor psikologi di Universitas Pennsylvania dan pernah menjabat sebagai anak panti American Psychological Association (APA) mulai berfikir bahwa manusia tidak hanya dapat dipelajari dari sisi negatifnya saja, tetapi juga dari sisi positifnya. Martin E. P Seligman menilai selama ini kajian psikologi sering diwarnai dengan topik negatif tentang manusia. Martin E. P Seligman juga berpendapat bahwa psikologi bukan hanya studi tentang penyakit, kelemahan, dan kerusakan, tetapi psikologi juga studi tentang kebahagiaan, kekuatan, dan kebajikan (Seligman, 2004).

Psikologi positif adalah perspektif ilmiah tentang bagaimana membuat hidup lebiih berharga. Martin E. P Seligman dalam pidato pelantikannya mengatakan bahwa sebelum perang dunia II, psikologi memiliki tiga misi yaitu menyembuhkan penyakit mental, membuat hidup lebih bahagia, dan mengidentifikasi serta membina bakat mulia dan kegeniusan. Setelah perang dunia II, dua misis psikologi yang terakhir diabaikan. Berdasarkan kondisi tersebut maka ditegakkan tiga tonggak utama psikologi positif, yaitu studi tentang emosi positif, studi tentang sifat-sifat positif, terutama tentang kekuatan dan kebajikan, dan studi tentang lembaga-lembaga positif yang mendukung kebajikan (Seligman, 2004)

\section{c. CBT (Cognitive Behavior Theraphy)}

Beck, (1964) mendefinisikan CBT sebagai pendekatan konseling yang dirancang untuk menyelesaikan permasalahan konseli pada saat ini dengan cara melakukan restrukturisasi kognitif dan perilaku yang menyimpang. Pedekatan CBT didasarkan pada formulasi kognitif, keyakinan dan strategi perilaku yang mengganggu. Proses konseling didasarkan pada konseptualisasi atau pemahaman konseli atas keyakinan khusus dan pola perilaku konseli. Harapan dari CBT yaitu munculnya restrukturisasi kognitif yang menyimpang dan sistem kepercayaan untuk membawa perubahan emosi dan perilaku ke arah yang lebih baik.

Matson, (1988) mengungkapkan definisi cognitive-behavior therapy yaitu pendekatan dengan sejumlah prosedur yang secara spesifik menggunakan kognisi sebagai bagian utama konseling. Fokus konseling yaitu persepsi, kepercayaan dan pikiran. Para ahli yang tergabung dalam National Association of Cognitive Behavioral Therapist (NACBT) mengungkapkan bahwa definisi dari cognitivebehavior therapy yaitu suatu pendekatan psikoterapi yang menekankan peran yang penting berpikir bagaimana kita merasakan dan apa yang kita lakukan, (NACBT, 2007).

Teori Cognitive-Behavior (Oemarjoedi, 2003) pada dasarnya meyakini pola pemikiran manusia terbentuk melalui proses Stimulus-Kognisi-Respon (SKR), 
yang saling berkaitan dan membentuk semacam jaringan SKR dalam otak manusia, di mana proses kognitif menjadi faktor penentu dalam menjelaskan bagaimana manusia berpikir, merasa dan bertindak. Sementara dengan adanya keyakinan bahwa manusia memiliki potensi untuk menyerap pemikiran yang rasional dan irasional, di mana pemikiran yang irasional dapat menimbulkan gangguan emosi dan tingkah laku yang menyimpang, maka CBT diarahkan pada modifikasi fungsi berfikir, merasa, dan bertindak dengan menekankan peran otak dalam menganalisa, memutuskan, bertanya, bertindak, dan memutuskan kembali. Dengan mengubah status pikiran dan perasaannya, konseli diharapkan dapat mengubah tingkah lakunya, dari negatif menjadi positif. Berdasarkan paparan definisi mengenai CBT, maka CBT adalah pendekatan konseling yang menitik beratkan pada restrukturisasi atau pembenahan kognitif yang menyim-pang akibat kejadian yang merugikan dirinya baik secara fisik maupun psikis. CBT merupakan konseling yang dilakukan untuk meningkatkan dan merawat kesehatan mental. Konseling ini akan diarahkan kepada modifikasi fungsi berpikir, merasa dan bertindak, dengan menekankan otak sebagai penganalisa, pengambil keputusan, bertanya, bertindak, dan memutuskan kembali. Sedangkan, pendekatan pada aspek behavior diarahkan untuk membangun hubungan yang baik antara situasi permasalahan dengan kebiasaan mereaksi permasalahan. Tujuan dari CBT yaitu mengajak individu untuk belajar mengubah perilaku, menenangkan pikiran dan tubuh sehingga merasa lebih baik, berpikir lebih jelas dan membantu membuat keputusan yang tepat. Hingga pada akhirnya dengan CBT diharapkan dapat membantu konseli dalam menyelaraskan berpikir, merasa dan bertindak.

Tujuan dari konseling Cognitive-Behavior (Oemarjoedi, 2003) yaitu mengajak konseli untuk menentang pikiran dan emosi yang salah dengan menampilkan buktibukti yang bertentangan dengan keyakinan mereka tentang masalah yang dihadapi. Konselor diharapkan mampu menolong konseli untuk mencari keyakinan yang sifatnya dogmatis dalam diri konseli dan secara kuat mencoba menguranginya.

Dalam proses konseling, beberapa ahli CBT (NACBT, 2007); (Oemarjoedi, 2003) berasumsi bahwa masa lalu tidak perlu menjadi fokus penting dalamkonseling. Oleh sebab itu CBT dalam pelaksanaan konseling lebih menekankan kepada masa kini dari pada masa lalu, akan tetapi bukan berarti mengabaikan masa lalu. CBT tetap menghargai masa lalu sebagai bagian dari hidup konseli dan mencoba membuat konseli menerima masa lalunya, untuk tetap melakukan perubahan pada pola pikir masa kini untuk mencapai perubahan di waktu yang akan datang. Oleh sebab itu, CBT lebih banyak bekerja pada status kognitif saat ini untuk dirubah dari status kognitif negatif menjadi status kognitif positif.

CBT merupakan konseling yang menitik beratkan pada restrukturisasi atau pembenahan kognitif yang menyimpang akibat kejadian yang merugikan dirinya baik secara fisik maupun psikis dan lebih melihat ke masa depan dibanding masa lalu. Aspek kognitif dalam CBT antara lain mengubah cara berpikir, kepercayaan, sikap, asumsi, imajinasi dan memfasilitasi konseli belajar mengenali dan mengubah kesalahan dalam aspek kognitif. Sedangkan aspek behavioral dalam CBT yaitu mengubah hubungan yang salah antara situasi permasalahan dengan kebiasaan mereaksi permasalahan, belajar mengubah perilaku, menenangkan pikiran dan tubuh sehingga merasa lebih baik, serta berpikir lebih jelas.

\section{d. Prinsip - Prinsip Cognitive-Behavior Therapy (CBT)}

Walaupun konseling harus disesuaikan dengan karakteristik atau permasalahan konseli, tentunya konselor harus memahami prinsip-prinsip yang mendasari CBT. Pemahaman terhadap prinsip-prinsip ini diharapkan dapat mempermudah konselor dalam memahami konsep, strategi dalam merencanakan proses konseling dari setiap sesi, serta penerapan teknik-teknik CBT. Berikut adalah 
prinsip-prinsip dasar dari CBT berdasarkan kajian yang diungkapkan oleh (Beck, 1964):

Prinsip pertama: Cognitive-Behavior Therapy didasarkan pada formulasi yang terus berkembang dari permasalahan konseli dan konseptualisasi kognitif konseli

Formulasi konseling terus diperbaiki seiring dengan perkembangan evaluasi dari setiap sesi konseling. Pada momen yang strategis, konselor mengkoordinasikan penemuan-penemuan konseptualisasi kognitif konseli yang menyimpang dan meluruskannya sehingga dapat membantu konseli dalam penyesuaian antara berfikir, merasa dan bertindak.

Prinsip kedua: Cognitive-Behavior Therapy didasarkan

pada pemahaman yang sama antara konselor dan konseli terhadap permasalahan yang dihadapi konseli. Melalui situasi konseling yang penuh dengan kehangatan, empati, peduli, dan orisinilitas respon terhadap permasalahan konseli akan membuat pemahaman yang sama terhadap permasalahan yang dihadapi konseli. Kondisi tersebut akan menunjukan sebuah keberhasilan dari konseling.

Prinsip ketiga: Cognitive-Behavior Therapy memerlukan kolaborasi dan partisipasi aktif.

Menempatkan konseli sebagai tim dalam konseling maka keputusan konseling merupakan keputusan yang disepakati dengan konseli. Konseli akan lebih aktif dalam mengikuti setiap sesi konseling, karena konseli mengetahui apa yang harus dilakukan dari setiap sesi konseling.

Prinsip keempat: Cognitive-Behavior Therapy berorienta-si pada tujuan dan berfokus pada permasalahan.

Setiap sesi konseling selalu dilakukan evaluasi untuk mengetahui tingkat pencapaian tujuan. Melalui evaluasi ini diharapkan adanya respon konseli terhadap pikiran-pikiran yang mengganggu tujuannya, dengan kata lain tetap berfokus pada permasalahan konseli.

Prinsip kelima: Cognitive-Behavior Therapy berfokus pada kejadian saat ini. Konseling dimulai dari menganalisis permasalahan konseli pada saat ini dan di sini (here and now). Perhatian konseling beralih pada dua keadaan. Pertama, ketika konseli mengungkapkan sumber kekuatan dalam melakukan kesalahannya. Kedua, ketika konseli terjebak pada proses berfikir yang menyimpang dan keyakinan konseli dimasa lalunya yang berpotensi merubah kepercayaan dan tingkahlaku ke arah yang lebih baik.

Prinsip keenam: Cognitive-Behavior Therapy merupakan edukasi, bertujuan mengajarkan konseli untuk menjadi terapis bagi dirinya sendiri, dan menekankan pada pencegahan.

Sesi pertama CBT mengarahkan konseli untuk mempelajari sifat dan permasalahan yang dihadapinya termasuk proses konseling cognitive-behavior serta model kognitifnya karena CBT meyakini bahwa pikiran mempengaruhi emosi dan perilaku. Konselor membantu menetapkan tujuan konseli, mengidentifikasi dan mengevaluasi proses berfikir serta keyakinan konseli. Kemudian merencanakan rancangan pelatihan untuk perubahan tingkah lakunya.

Prinsip ketujuh: Cognitive-Behavior Therapy berlangsung pada waktu yang terbatas.

Pada kasus-kasus tertentu, konseling membutuhkan pertemuan antara enam sampai empat belas sesi. Agar proses konseling tidak membutuhkan waktu yang panjang, diharapkan secara kontinyu konselor dapat membantu dan melatih konseli untuk melakukan self-help.

Prinsip kedelapan: Sesi Cognitive-Behavior Therapy yang terstruktur.

Struktur ini terdiri dari tiga bagian konseling. Bagian awal, menganalisis perasaan dan emosi konseli, menganalisis kejadian yang terjadi dalam satu 
minggu kebelakang, kemudian menetapkan agenda untuk setiap sesi konseling. Bagian tengah, meninjau pelaksanaan tugas rumah (homework asigment), membahas permasalahan yang muncul dari setiap sesi yang telah berlangsung, serta merancang pekerjaan rumah baru yang akan dilakukan. Bagian akhir, melakukan umpan balik terhadap perkembangan dari setiap sesi konseling. Sesi konseling yang terstruktur ini membuat proses konseling lebih dipahami oleh konseli dan meningkatkan kemungkinan mereka mampu melakukanself-help di akhir sesi konseling.

Prinsip kesembilan: Cognitive-Behavior Therapy mengajarkan konseli untuk mengidentifikasi, mengevaluasi dan menanggapi pemikiran disfungsional dan keyakinan mereka.

Setiap hari konseli memiliki kesempatan dalam pikiran-pikiran otomatisnya yang akan mempengaruhi suasana hati, emosi dan tingkah laku mereka. Konselor membantu konseli dalam mengidentifikasi pikirannya serta menyesuaikan dengan kondisi realita serta perspektif adaptif yang mengarahkan konseli untuk merasa lebih baik secara emosional, tingkahlaku dan mengurangi kondisi psikologis negatif. Konselor juga men-ciptakan pengalaman baru yang disebut dengan eksperimen perilaku. Konseli dilatih untuk menciptakan pengalaman barunya dengan cara menguji pemikiran mereka (misalnya: jika saya melihat gambar labalaba, maka akan saya merasa sangat cemas, namun saya pasti bisa menghilangkan perasaan cemas tersebut dan dapat melaluinya dengan baik). Dengan cara ini, konselor terlibat dalam eksperimen kolaboratif. Konselor dan konseli bersama-sama menguji pemikiran konseli untuk mengembangkan respon yang lebih bermanfaat dan akurat.

Prinsip kesepuluh: Cognitive-Behavior Therapy menggunakan berbagai teknik untuk merubah pemikiran, perasaan, dan tingkah laku.

Pertanyaan pertanyaan yang berbentuk sokratik memudahkan konselor dalam melakukan konseling cognitive-behavior.

Pertanyaan dalam bentuk sokratik merupakan inti atau kunci dari proses evaluasi konseling. Dalam proses konseling, CBT tidak mempermasalahkan konselor menggunakan teknik-teknik dalam konseling lain seperti kenik Gestalt, Psikodinamik, Psikoanalisis, selama teknik tersebut membantu proses konseling yang lebih saingkat dan memudahkan konelor dalam membantu konseli. Jenis teknik yang dipilih akan dipengaruhi oleh konseptualisasi konselor tehadap konseli, masalah yang sedang ditangani, dan tujuan konselor dalam sesi konseling tersebut.

Strategi penelitian yang digunakan dalam kajian ini adalah Action Research. Metode Action Research merupakan salah satu model penelitian yang mencari sesuatu untuk menghubungkan proses penelitian ke dalam proses perubahan sosial. Adapun strategi yang digunakan dalam melakukan action research ini dapat digambarkan sebagai berikut: 


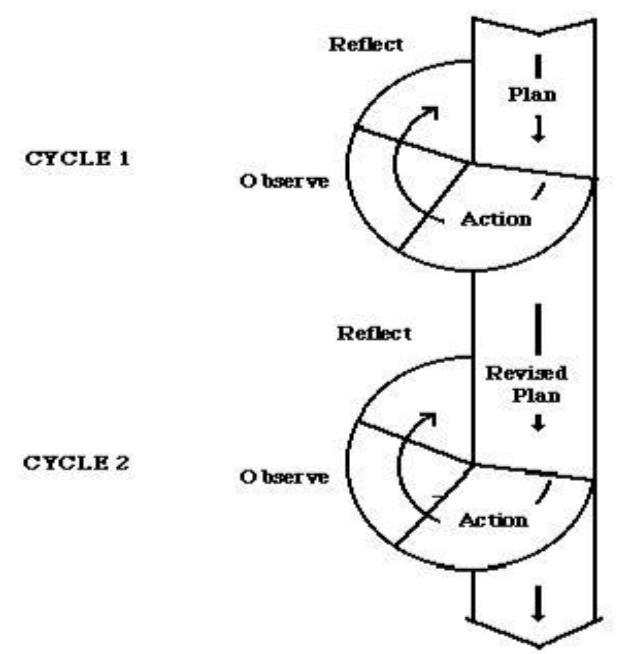

Figure 1 Simple Action Research Model

(diadaptasi dari MacIsaac, 1995) dalam (Srinivasan, 2011)

Proses analisis data dimulai dengan menelaah seluruh data yang tersedia dari berbagai sumber, yaitu dari wawancara, pengamatan yang telah dituliskan dalam catatan lapangan, dokumen resmi, gambar, foto, dan sebagainya. Analisis data dalam penelitian kualitatif dilakukan pada saat pengumpulan data seperti yang dikemukakan oleh (Miles, M.B. \& Huberman, 1992) bahwa aktivitas dalam analisis data kualitatif dilakukan secara interaktif dan berlangsung secara terus menerus sampai tuntas, sehingga datanya jenuh. Aktivitas dalam menganalisis data kualitatif yaitu:

1) Reduksi Data (Data Reduction)

Mereduksi data berarti merangkum, memilih hal-hal yang pokok, memfokuskan pada hal-hal yang penting, dicari tema dan polanya. Dengan demikian data yang telah direduksi akan memberikan gambaran yang lebih jelas dan mempermudah peneliti untuk melakukan pengumpulan data selanjutnya dan mencarinya bila diperlukan. Secara teknis, pada kegiatan reduksi data yang telah dilakukan dalam penelitian ini meliputi: perekapan hasil wawanacara kemudian pengamatan hasil pengumpulan dokumen yang berhubungan dengan fokus penelitian.

2) Penyajian Data (Data Display)

Menyajikan data yaitu penyusunan sekumpulan informasi yang memberi kemungkinan adanya penarikan kesimpulan dan penarikan tindakan. Dalam penelitian kualitatif, penyajian data bisa dilakukan dalam bentuk uraian singkat, bagan, hubungan antar kategori, flowchart atau sejenisnya. Dalam penelitian ini, secara teknis data-data akan disajikan dalam bentuk teks naratif, tabel, foto, bagan.

3) Penarikan Kesimpulan (Conclusion Drawing)

Langkah ketiga dalam analisis data menurut Miles dan Huberman adalah penarikan kesimpulan dan verifikasi. Kesimpulan dalam penelitian kualitatif adalah merupakan temuan baru yang sebelumnya belum pernah ada. Dengan demikian kesimpulan dalam penelitian kualitatif mungkindapat menjawab rumusan masalah yang dirumuskan sejak awal, tetapi mungkin juga tidak karena masalah dan rumusan masalah dalam penelitian kualitatif masih bersifat sementara dan akan berkembang setelah penelitian berada dilapangan. Secara teknis proses penarikan kesimpulan dalam penelitian ini akan dilakukan dengan cara mendiskusikan data-data hasil temuan dilapangan dengan teori-teori yang 
dimasukan dalam bab tinjauan pustaka.

Dari gambaran proses penelitian action research ini ada empat tahapan dalam melakukan penelitian ini, yaitu:

1) Perencanaan (plan)

Perencanaan ini dilakukan setelah memperhatikan kondisi riil remaja Panti Asuhan Aisyiah 2 dengan menggunakan analisis SWOT. Perencanaan ini meliputi strategi dan metode dalam memecahkan problematika.

2) Tindakan (action)

Implementasi rencana yang telah dibuat tersebut dengan dibantu dan difasilitasi oleh peneliti.

3) Pengamatan (observe)

Pengamatan dilakukan untuk memperhatikan dan menganalisis keberhasilan, kelemahan, dan kekurangan strategi dan metode yang digunakan dalam menyelesaikan problematika remaja yang terjadi di masyarakat. Demikian pula faktor-faktor pendukung dan penghambat yang teridentifikasi selama kegitan berlangsung.

4) Refleksi (reflect)

Usaha-usaha yang telah dilakukan dalam memecahkan problematika remaja di Panti Asuhan Aisiyiah 2 direfleksikan dan dievaluasi, baik kekurangan, kelemahan, dan keberhasilan strategi dan metode dalam memecahkan problematika tersebut. Refleksi dan evaluasi ini berujung kepada perencanaan (plan) seperti pada poin pertama untuk menuntaskan problematika masyarakat, baik yang belum tuntas pada tahap pertama atau untuk memecahkan problematika yang baru.

Berdasarkan isu-isu kritis kerentanan kekerasan seksual pada anak dan strategi yang digunakan dalam PAR di atas, maka bentuk kegiatan yang akan dilakukan dalam penelitian action research ini antara lain:

1) Wawancara mendalam (indepth interview)

2) Observasi

3) Focus Group Discussion (FGD) untuk mengakomodir kebutuhan dan permasalahan masyarakat di Dukuh Bentur (Need Assesment)

\section{Hasil dan Pembahasan}

Cognitive behaviour therapy (CBT) merupakan pendekatan terapi yang berpusat pada proses berfikir dan kaitannya dengan keadaan emosi, perilaku, dan psikologi. CBT berpusat pada ide bahwa orang tertentu mampu mengubah kognisi mereka, dan karenanya mengubah dampak pemikiran pada kesejahteraan emosi mereka. ${ }^{1}$

Cognitive Behavioral Therapy (CBT) merupakan psikoterapi yang menggabungkan antara terapi perilaku dan terapi kognitif yang didasarkan pada asumsi bahwa perilaku manusia secara bersama dipengaruhi oleh pemikiran, perasaan, proses fisiologis serta konsekuensinya pada perilaku. ${ }^{2}$ Teknik dan Metode Konseling kognitif-behavioral cenderung menggunakan sebuah program yang terstruktur langkah demi langkah Program yang dapat mencakup:

1) Menciptakan hubungan yang sangat dekat dengan aliansi kerja antara konselor dan konseli. Menjelaskan dasar pemikiran dari penanganan yang akan diberikan.

\footnotetext{
${ }^{1}$ Christine Wilding dan Aileen Milne, Cognitive Behavior Therapy, (Jakarta: Indeks, 2013), hlm. 18

${ }^{2}$ Ni Putu Diah Prabandari, Pengaruh Cognitive Behavioral Therapy (CBT) terhadap Post Traumatic Sress Disorder (PTSD) pada Pasien Post Kecelakaan Lalu Lintas di RSUP sanglah Denpasar, Jurnal Studi Ilmu Keperawatan Fakultas Kedokteran Universitas Udayana, Vol.3 No.2, Mei-Agustus 2015, hlm.22.
} 
2) Menilai masalah. Mengidentifikasi, mengukur frekuensi, intensitas dan kelayakan masalah perilaku, dan kognisi.

3) Menetapkan target perubahan.

4) Penerapan teknik kognitif dan behavioural (perilaku)

5) Memonitor perkembangan, dengan menggunakan penilaian berjalan terhadap perilaku sasaran.

6) Mengakhiri dan merancang program lanjutan untuk menguatkan dari apa yang didapat. $^{3}$

Terapi kognitif adalah salah satu bentuk psikoterapi yang didasarkan pada konsep patologi jiwa, dimana fokus dari tindakannya berdasarkan modifikasi dari distorsi kognitif dan perilaku maladaptive (Townsend, M. C, 2009). Menurut (Nevid, J. S., Rathus, S. A., \& Greene, 2003) terapi kognitif juga fokus untuk membantu klien mengidentifikasi dan mengkoreksi pikiran maladaptive, jenis pikiran otomatis, dan mengubah perilaku sendiri yang disebabkan oleh berbagai masalah-masalah emosional (Beck, 1964); (Townsend, M. C, 2009) mengungkapkan tujuan dari terapi kognitif adalah sebagai monitor pikiran otomatis negative, mengetahui hubungan antara pikiran, perasaan dan perilaku, mengubah penalaran yang salah menjadi penalaran yang logis, dan membantu pasien mengidentifikasi dan mengubah kepercayaan yang salah sebagai pengalaman negative internal pasien. Pemberian terapi kognitif diharapkan dapat merubah pikiran otomatis negatif klien menjadi pikiran positif.

CBT merupakan kombinasi dari terapi cognitive dan behaviour, dan memiliki pengaruh untuk mengatasi gangguan mood dan ansietas (Ollendick., 2001). CBT adalah salah satu bentuk terapi komunikasi (Maryati, 2015) sehingga dapat dikatakan bahwa CBT merupakan terapi yang menggunakan pendekatan penyelesaian masalah dengan mempelajari cara pengontrolan pikiran melalui perubahan persepsi terhadap orang dan situasi tertentu.

Stallard, (2002), menyebutkan bahwa CBT adalah intervensi terapeutik yang bertujuan untuk mengurangi tingkah laku mengganggu dan maladaptif dengan mengembangkan proses kognitif. CBT didasarkan pada asumsi bahwa afek dan tingkah laku adalah produk dari kognitif. Oleh karena itu intervensi kognitif dan tingkah laku dapat membawa perubahan dalam pikiran, perasaan, dan tingkah laku CBT pada dasarnya bertujuan untuk mengubah keadaan atau status emosi individu, akan tetapi emosi tidak dapat diintervensi secara langsung. Emosi dihasilkan dari adanya stimulasi internal dan eksternal dan dipengaruhi oleh adanya perubahan pola pikir dan perilaku. Tujuan untuk menstabilkan emosi dapat dicapai dengan menggunakan CBT bertujuan untuk menciptakan ketrampilan yang memungkinkan individu untuk meningkatkan kesadaran akan pikiran dan perasaannya, mengidentifikasi bagaimana situasi, pikiran dan perilaku mempengaruhi perasaan dan meningkatkan kemampuan untyk merubah pikiran dan perilaku maladaptive.

Martin (2010) menyatakan bahwa penerapan terapi psikososial dengan perilaku kognitif dapat merubah pola piker yang negative menjadi positif sehingga perilaku yang maladaptive yang timbul akibat pola piker yang salah juga akan berubah menjadi perilaku yang adaptif, sehingga pada akhirnya diharapkan individu dengan masalah isolasi sosial memiliki peningkatan kemampuan untuk melakukan interaksi sosial dan bereaksi secara adaptif dalam menghadapi masalah atau situasi yang sulit dalam setiap fase hidupnya.

Berdasarkan penelitian (Fauziah, 2009) mengatakan bahwa terapi perilaku kognitif dapat meningkatkan kemampuan kognitif dan perilaku klien skizofrenia

\footnotetext{
${ }^{3}$ John Mcleod, Pengantar Konseling: Teori dan Studi Kasus, Edisi Ketiga Cet. 1 (Jakarta: Kencana, 2006). Hlm. 157.
} 
dengan perilaku kekerasan, (Sasmita, 2007) Cognitive behaviour therapy (CBT) meningkatkan secara bermakna kemampuan kognitif dan perilaku klien harga diri rendagh, (Wahyuni, S. E., Keliat, B. A., 2010) mengatakan terapi perilaku kognitif dapat meningkatkan kemampuan kognitif dan perilaku klien halusinasi, (Erwina, 2010) mengatakan terapi perilaku kognitif dapat meningkatkan kemampuan kognitif dan perilaku klien pasca gempa.

Dalam contoh satu masalah yang dihadapi anak panti, di anataranya adalah masalah Bullying. Pemahaman anak-anak dan remaja tentang kondisi yang mereka alami, seperti bullying cukup beragam. Berdasarkan observasi yang dilakukan terhadap remaja putri di panti asuhan tersebut, salah satunya, anak panti dalam memahami bullying sebagai suatu tindakan yang merugikan bagi pelaku maupun korban. Mereka berpendapat bahwa bullying adalah suatu tindakan kekerasan yang dilakukan oleh pihak yang kuat terhadap pihak yang lemah. Menurut (Smith, P. K., D. Pepler, 2004), bullying adalah suatu aksi negatif yang secara intens bertujuan untuk mengintimidasi serta menyakiti orang lain. Bullying juga didefinisikan sebagai penyalahgunaan kekuasaan. Bullying dilakukan oleh seseorang maupun sekelompok anak muda pada orang yang lebih lemah. Tetapi bukan bullying jika kedua orang yang sama kuatnya sedang bersitegang atau berkelahi.

Faktor penyebab bullying karena perbedaan etnis, resistensi terhadap tekanan kelompok, perbedaan keadaan fisik, masuk di sekolah yang baru, orientasi seksual serta latar belakang sosial ekonomi. Faktor penyebab terjadinya bullying oleh siswa pada umumnya sama, yaitu faktor senioritas, meniru serta pengalaman masa lalu. Sesuai dengan pendapat (Harvey, 2006); (Lodge, 2007) di Indonesia sejak lima tahun terakhir gejala bullying di sekolah mulai diperhatikan oleh media massa, walaupun dengan istilah yang berbeda-beda. Dalam bahasa pergaulan sehari-hari sering disebutkan sebagai kata 'gencet-gencetan'. Hal tersebut juga sesuai dengan teori belajar sosial oleh Bandura bahwa perilaku kekerasan merupakan perilaku yang dipelajari dari pengalaman masa lalu, apakah melalui pengamatan langsung (imitasi), pengukuh positif dan karena stimulus diskriminatif.

Beberapa wujud bullying yang pernah terjadi di asrama maupun sekolah adalah berupa intimidasi, pemalakan, pemukulan, ucapan-ucapan kotor dan melecehkan. Intimidasi dilakukan dengan menggunakan kata-kata yang keras atau yang disebut dengan bullying verbal. Kendati para anak tinggal di asrama yang cukup dengan aturan dan rutinitas beribadah, tetapi masih terdapat perilaku bullying yang sangat merugikan bagi penghuninya. Bullying dapat terjadi diberbagai tempat, kapanpun, dan pada siapa saja. Penelitian sebelumnya menunjukkan bahwa bullying dapat terjadi di rumah tangga, sekolah dan lingkungan kampus (Mafriana, 2005)

Tabel 1 Matriks Penilaian 'Program Terapi CBT dalam mengembangkan kepribadian remaja putri di Panti'

\begin{tabular}{llllc}
\hline \multicolumn{1}{c}{ Kategori } & Keterampilan & \multicolumn{1}{c}{ Deskripsi } & Matrix & \multicolumn{1}{c}{ Capaian } \\
\hline Afektif & $\begin{array}{l}\text { Melatih } \\
\text { Kembali } \\
\text { pernafasan }\end{array}$ & $\begin{array}{l}\text { Bernafas lewat } \\
\text { diafragma lambat- } \\
\text { lambat dan dalam- } \\
\text { dalam untuk } \\
\text { menurunkan } \\
\text { kecemasan dan stress }\end{array}$ & 4 & $\begin{array}{l}\text { Berkembang } \\
\text { dengan baik }\end{array}$ \\
\hline $\begin{array}{l}\text { Afektif } \\
\text { Amarah }\end{array}$ & $\begin{array}{l}\text { Mengendalikan } \\
\text { kemarahan }\end{array}$ & $\begin{array}{l}\text { Mengelola amarah } \\
\text { melalui penghentian } \\
\text { pikiran, melatih }\end{array}$ & 4 & $\begin{array}{l}\text { Berkembang } \\
\text { dengan baik }\end{array}$ \\
\hline
\end{tabular}




\begin{tabular}{|c|c|c|c|c|}
\hline Kategori & Keterampilan & Deskripsi & Matrix & Capaian \\
\hline & & $\begin{array}{l}\text { relaksas, melatih } \\
\text { pemecahan masalah } \\
\text { (problem-solving) }\end{array}$ & & \\
\hline $\begin{array}{l}\text { Afektif- } \\
\text { Impulsif }\end{array}$ & $\begin{array}{l}\text { Manajemen } \\
\text { Kontingensi }\end{array}$ & $\begin{array}{l}\text { Manajemen kontingensi } \\
\text { menggunakan prinsip- } \\
\text { prinsip perubahan } \\
\text { perilaku untuk } \\
\text { mengatasi impulsivitas } \\
\text { dan melatih } \\
\text { pengendalian diri }\end{array}$ & 3 & $\begin{array}{l}\text { Berkembang } \\
\text { dengan baik }\end{array}$ \\
\hline $\begin{array}{l}\text { Afektif } \\
\text { suasana Hati }\end{array}$ & $\begin{array}{l}\text { Keterampilan } \\
\text { Perilaku }\end{array}$ & $\begin{array}{l}\text { Pembentukan } \\
\text { keterampilan } \\
\text { behavioural secara } \\
\text { kognitif untuk } \\
\text { manajemen susasana } \\
\text { hati }\end{array}$ & 4 & $\begin{array}{l}\text { Berkembang } \\
\text { dengan baik }\end{array}$ \\
\hline Kognitif & Defusi kognitif & $\begin{array}{l}\text { Belajar untuk tidak } \\
\text { menerima pikiran- } \\
\text { pikiran yang muncul } \\
\text { sekilas atau yang dinilai } \\
\text { secara sekilas }\end{array}$ & 4 & $\begin{array}{l}\text { Berkembang } \\
\text { dengan baik }\end{array}$ \\
\hline Kognitif & $\begin{array}{l}\text { Cognitive } \\
\text { Restructuring }\end{array}$ & $\begin{array}{l}\text { Belajar untuk menolak } \\
\text { distorsi-ditorsi kognitif, } \\
\text { dan menggantikannya } \\
\text { dengan pikiran-pikiran } \\
\text { yang lebih sehat }\end{array}$ & 3 & $\begin{array}{l}\text { Berkembang } \\
\text { dengan baik }\end{array}$ \\
\hline Kognitif & $\begin{array}{l}\text { Penyadaran } \\
\text { Penuh } \\
\text { (mindfullness) }\end{array}$ & $\begin{array}{l}\text { Membangun kesadaran } \\
\text { yang penuh tentang apa } \\
\text { yang ada (dari } \\
\text { pengalaman langsung) } \\
\text { melalui kontak dengan } \\
\text { momen saat ini, } \\
\text { penerimaan, dan } \\
\text { sebagainya. }\end{array}$ & 4 & $\begin{array}{l}\text { Berkembang } \\
\text { dengan baik }\end{array}$ \\
\hline $\begin{array}{l}\text { Toleransi } \\
\text { Hendaya }\end{array}$ & $\begin{array}{l}\text { Penerimaan } \\
\text { psikologis }\end{array}$ & $\begin{array}{l}\text { Belajar untuk } \\
\text { menerima (bukannya } \\
\text { melawan) pikiran dan } \\
\text { peasaan yang tidak } \\
\text { diinginkan melalui } \\
\text { pengefektifan, } \\
\text { pengaturan emosi, } \\
\text { toleransi hendaya dan } \\
\text { mindfulness. }\end{array}$ & 4 & $\begin{array}{l}\text { Berkembang } \\
\text { dengan baik }\end{array}$ \\
\hline $\begin{array}{l}\text { Toleransi } \\
\text { Hendaya }\end{array}$ & $\begin{array}{l}\text { Toleransi } \\
\text { Hendaya }\end{array}$ & $\begin{array}{l}\text { Mengalami peristiwa- } \\
\text { peristiwa pribadi yang } \\
\text { sulit namun tanpa } \\
\text { membiarkan mereka } \\
\text { menjadi pengganggu } \\
\text { bagi tujuan-tujuan } \\
\text { hidup }\end{array}$ & 3 & $\begin{array}{l}\text { Berkembang } \\
\text { dengan baik }\end{array}$ \\
\hline
\end{tabular}




\begin{tabular}{|c|c|c|c|c|}
\hline Kategori & Keterampilan & Deskripsi & Matrix & Capaian \\
\hline $\begin{array}{l}\text { Toleransi } \\
\text { Hendaya }\end{array}$ & $\begin{array}{l}\text { Pengaturan } \\
\text { emosi }\end{array}$ & $\begin{array}{l}\text { Belajar untuk } \\
\text { memepengaruhi } \\
\text { bagaimana emosi- } \\
\text { emosi dialami dan } \\
\text { diekspresikan }\end{array}$ & 3 & $\begin{array}{l}\text { Berkembang } \\
\text { dengan baik }\end{array}$ \\
\hline $\begin{array}{l}\text { Toleransi } \\
\text { Hendaya }\end{array}$ & $\begin{array}{l}\text { Manajemen } \\
\text { rasa sakit atau } \\
\text { mengatasi } \\
\text { masalah }\end{array}$ & $\begin{array}{l}\text { Keterampilan- } \\
\text { keterampilan untuk } \\
\text { mengatur diri sendiri } \\
\text { dan mengelola stress } \\
\text { untuk mengatasi } \\
\text { masalah (coping) yang } \\
\text { berupa kesendirian, } \\
\text { basic ancietas }\end{array}$ & 3 & $\begin{array}{l}\text { Berkembang } \\
\text { dengan baik }\end{array}$ \\
\hline $\begin{array}{l}\text { Toleransi } \\
\text { Hendaya }\end{array}$ & Relaksasi & $\begin{array}{l}\text { Menggunakan teknik- } \\
\text { teknik seperti } \\
\text { peregangan dan } \\
\text { pengendoran otot, } \\
\text { imajinasi terpadu dan } \\
\text { pengendalian petunjuk } \\
\text { untuk mengembangkan } \\
\text { relaksasi dan } \\
\text { meredakan } \\
\text { ketegangan/tekanan }\end{array}$ & 4 & $\begin{array}{l}\text { Berkembang } \\
\text { dengan baik }\end{array}$ \\
\hline $\begin{array}{l}\text { Toleransi } \\
\text { Hendaya }\end{array}$ & $\begin{array}{l}\text { Pencegahan } \\
\text { respons }\end{array}$ & $\begin{array}{l}\text { Membuat klien } \\
\text { terpapar situasi-situasi } \\
\text { yang memunculkan } \\
\text { kecemasan sembari } \\
\text { mencegah perilaku } \\
\text { melarikan diri atau } \\
\text { menghindar: } \\
\text { membantu pemunahan } \\
\text { terhadap respons yang } \\
\text { ditakuti }\end{array}$ & 3 & $\begin{array}{l}\text { Berkembang } \\
\text { dengan baik }\end{array}$ \\
\hline $\begin{array}{l}\text { Toleransi } \\
\text { Hendaya }\end{array}$ & $\begin{array}{l}\text { Manajemen } \\
\text { stress }\end{array}$ & $\begin{array}{l}\text { Format tipikal } \\
\text { pelaksanaannya adala } \\
\text { terapi kelompok (8-10 } \\
\text { sesi). Komponen- } \\
\text { komponen penanganan } \\
\text { yang tipikal meliputi } \\
\text { keterampilan } \\
\text { mengatasi masalah } \\
\text { dengan berfokus } \\
\text { kepada masalah, } \\
\text { desensitisasi sistematis, } \\
\text { pernapasan } \\
\text { diafragmatik, dan } \\
\text { penghentian kognitif } \\
\text { dengan tujuan } \\
\text { mereduksi tingkatan } \\
\text { stres }\end{array}$ & 4 & $\begin{array}{l}\text { Berkembang } \\
\text { dengan baik }\end{array}$ \\
\hline
\end{tabular}




\begin{tabular}{|c|c|c|c|c|}
\hline Kategori & Keterampilan & Deskripsi & Matrix & Capaian \\
\hline $\begin{array}{l}\text { Melatih } \\
\text { Keterampilan } \\
\text { khusus- } \\
\text { komunikasi }\end{array}$ & $\begin{array}{l}\text { Aserivitas } \\
\text { (menjadi } \\
\text { tegas) }\end{array}$ & $\begin{array}{l}\text { Belajar untuk } \\
\text { mengemukakan dan } \\
\text { menolak permintaan } \\
\text { orang lain, dan } \\
\text { mengomunikasikan } \\
\text { opini-opini dan } \\
\text { perasaan -perasaan } \\
\text { yang kuat }\end{array}$ & 3 & $\begin{array}{l}\text { Berkembang } \\
\text { dengan baik }\end{array}$ \\
\hline $\begin{array}{l}\text { Melatih } \\
\text { Keterampilan } \\
\text { khusus- } \\
\text { komunikasi }\end{array}$ & $\begin{array}{l}\text { Komunikasi } \\
\text { atau } \\
\text { Pemecahan } \\
\text { masalah } \\
\text { Keluarga }\end{array}$ & $\begin{array}{l}\text { Penekanan terhadap } \\
\text { perilaku mendengar } \\
\text { dan berbicara, dan } \\
\text { ketrampilan } \\
\text { memecahkan masalah } \\
\text { (problem solving) }\end{array}$ & 4 & $\begin{array}{l}\text { Berkembang } \\
\text { dengan baik }\end{array}$ \\
\hline $\begin{array}{l}\text { Melatih } \\
\text { Keterampilan } \\
\text { khusus }\end{array}$ & $\begin{array}{l}\text { Keterampilan } \\
\text { menjalin } \\
\text { hubungan } \\
\text { antar pribadi }\end{array}$ & $\begin{array}{l}\text { Mengembangkan } \\
\text { keterampilan- } \\
\text { keterampilan antar } \\
\text { pribadi sebagai cara } \\
\text { untuk menghadapi } \\
\text { agresi, kecemasan, } \\
\text { depresi dan untuk } \\
\text { meningkatkan } \\
\text { efektivitas di komunitas } \\
\text { panti }\end{array}$ & 3 & $\begin{array}{l}\text { Berkembang } \\
\text { dengan baik }\end{array}$ \\
\hline $\begin{array}{l}\text { Melatih } \\
\text { Keterampilan } \\
\text { khusus- } \\
\text { pendidikan }\end{array}$ & $\begin{array}{l}\text { Manajemen } \\
\text { ruang panti }\end{array}$ & $\begin{array}{l}\text { Prosedur-prosedur } \\
\text { yang proaktif dan } \\
\text { reaktif untuk menolong } \\
\text { guru-guru dan } \\
\text { pendamping panti } \\
\text { mempertahankan } \\
\text { ketertiban berinteraksi } \\
\text { di lingkungan panti }\end{array}$ & 3 & $\begin{array}{l}\text { Berkembang } \\
\text { dengan baik }\end{array}$ \\
\hline $\begin{array}{l}\text { Melatih } \\
\text { Keterampilan } \\
\text { khusus- } \\
\text { parenting }\end{array}$ & $\begin{array}{l}\text { Melatih orang } \\
\text { tua }\end{array}$ & $\begin{array}{l}\text { Penggunaan metode- } \\
\text { metode perilaku } \\
\text { mendasar (penguatan } \\
\text { positif, hukuman } \\
\text { ringan) untuk } \\
\text { membentuk perilaku } \\
\text { anak }\end{array}$ & 3 & $\begin{array}{l}\text { Berkembang } \\
\text { dengan baik }\end{array}$ \\
\hline $\begin{array}{l}\text { Melatih } \\
\text { Keterampilan } \\
\text { khusus- } \\
\text { parenting }\end{array}$ & $\begin{array}{l}\text { Pengamanan } \\
\text { atau } \\
\text { pencegahan } \\
\text { kekerasan }\end{array}$ & $\begin{array}{l}\text { Program pelatihan } \\
\text { perilaku bagi orang tua } \\
\text { untuk membantu } \\
\text { mereduksi pengabaian } \\
\text { dan penganiayaan } \\
\text { terhadap anak }\end{array}$ & 3 & $\begin{array}{l}\text { Berkembang } \\
\text { dengan baik }\end{array}$ \\
\hline $\begin{array}{l}\text { Melatih } \\
\text { Keterampilan } \\
\text { khusus }\end{array}$ & $\begin{array}{l}\text { Keterampilan- } \\
\text { keterampilan } \\
\text { keluarga }\end{array}$ & $\begin{array}{l}\text { Melatih orang tua dan } \\
\text { anak untuk } \\
\text { memperbaiki fungsi } \\
\text { keluarga }\end{array}$ & 3 & $\begin{array}{l}\text { Berkembang } \\
\text { dengan baik }\end{array}$ \\
\hline
\end{tabular}


Sebagaimana tujuan Penelitian yang disebutkan tersebut maka program penelitian dengan subjek penelitian remaja putri, sebagai generasi muslim penerus yang memiliki kesadaran akan perannya dan mampu mengoptimalkan serta mengaktualkan potensinya di masa yang akan datang. Untuk itu aspek-aspek yang ingin dijawab dari permasalahan penelitian merupakan aspek yang menjadi parameter kesiapan remaja putri di PAP Aisyiyah 2 tersebut. Capain program terapi CBT, di antaranya yaitu:

1) Terbentuknya pola pikir yang berorientasi pada pengembangan diri dan kepribadian (growth mindset) dalam segala hal yang ingin dicapai oleh para remaja putri, baik dalam hal prestasi akademis, keterampilan, sosial, keagamaan maupun psikologis.

2) Terciptanya motivasi intrinsik pada remaja putri yaitu keinginan untuk berhasil yang berasal dari diri sendiri dan menampilkan kepercayaan diri serta kemandirian.

3) Terciptanya sifat yang optimis dan kemampuan untuk menemukan arti kebahagiaan yang hakiki.

4) Terciptanya ketahanan diri (resilience) dan kemauan untuk berusaha dalam menghadapi situasi yang sulit dengan mempertahankan pola pikir yang positif.

5) Remaja putri menguasai keterampilan untuk memusatkan pikiran pada kegiatan yang sedang dilakukan, menciptakan garis perbedaan yang jelas antara satu situasi dengan situasi lain dan menjadi fleksibel. Selain itu, remaja putri mampu menemukan passion dan kekuatan diri, serta menjadi muslimah yang lebih taqwa dan tawakkal.

6) Para pengajar dan pengasuh menjadi terampil dalam memberikan pengajaran, pengasuhan dan pendampingan dengan menerapkan pendekatan CBT.

7) Terciptanya lingkungan dan sistem di dalam panti yang memfasilitasi ketahanan pola piker dan pemberdayaan remaja sebagai pribadi yang bahagia, optimis, tangguh, religius, dan bermanfaat.

\section{Kesimpulan}

Berdasarkan hasil analisis secara kualitatif, serta pembahasan yang sudah dipaparkan di atas bahwa program pengembangan kepribadian remaja putri yang berada di panti asuhan dengan pendekatan Cognitive Behaviour Therapy dapat meningkatkan kemampuan kognitif dan perilaku subjek penelitian. Subjek penelitian melakukan interaksi sosial dengan baik, sehingga subjek penelitian tetap menjaga hubungan atau kontak sosial, sehingga subjek penelitian merasa tidak sendiri. Penerapan terapi perilaku kognitif menunjukkan perubahan status pikiran dan perilaku subjek penelitian, sehingga perilaku negative yang muncul menjadi perilaku yang positif.

Faktor penyabab bullying biasanya dipengaruhi oleh keluarga, sekolah, dan faktor kelompok teman sebaya. Karakteristik perilaku bullying antara lain adalah Adanya perilaku agresi yang menyenangkan pelaku untuk menyakiti korban, Tindakan dilakukan secara tidak seimbang sehingga korban merasa tertekan serta Perilaku ini dilakukan secara terus menerus dan juga berulang-ulang. Secara keseluruhan proses pemberian terapi CBT mengubah cara berpikir dan berperilaku individu dari isolasi sosial mengarah pada interaksi sosial dan tidak mengarah pada maladaptive, meningkatkan kepercayaan subjek penelitian dalam melakukan interaksi subjek penelitian dengan orang lain dan mengurangi pikiran negative yang muncul.

Sikap dan cara pandang pengasuh panti terhadap upaya pengembangan kepribadian tergolong cukup baik. Penghuni panti khususnya pengurus dan pengasuh bersedia dan siap berpartisipasi untuk mengadakan kegiatan seperti sosialisasi 
kepada masyarakat, maupun kegiatan-kegiatan yang meningkatkan kapasitas pemahaman dan pengetahuan serta cara pengembangan kepribadian anak panti. Evaluasi partisipatif dilakukan untuk membahas evaluasi dari keberlanjutan program. Sementara, program dalam masa sosialisasi awal maka kegiatan ini belum dapat di lihat efeknya secara langsung. Maka yang bisa dilihat dari program terapi CBT ini adalah kesiapan dan partisipati pengurus dan pengasuh panti dalam menjalankan program pengembangan kepribadian.

Pemberdayaan masyarakat adalah proses yang berkelanjutan sehingga evaluasi pemberdayaan masyarakat sebaiknya dilakukan secara bertahap dimulai dari sebelum program dilaksanakan, awal pelaksanaan program, dan evaluasi periodik setelah pelaksanaan program, untuk itu diperlukan studi lebih lanjut mengenai evaluasi pemberdayaan pada tiap-tiap tahapan dalam pelaksanaan pemberdayaan tersebut.

Hasil penelitian ini diharapkan dapat menambah pengetahuan dalam ilmu psikologi khususnya tentang motiv santri yang melakukan bullying pada lingkungan panti dan sekolah agar bersama-sama dengan guru atau pengurus panti untuk memberikan penyuluhan kepada siswa untuk tidak melakukan bullying dan dampaknya serta menyarankan kepada siswa untuk tidak melakukan bullying secara verbal ataupun fisik kepada temannya. Selain sekolah, keluarga terutama orang tua juga memiliki peran penting dalam mencegah bullying disekolah. Caranya, orang tua bisa membangun komunikasi yang dekat dan sebaik mungkin dengan anak supaya anak bisa terbuka dengan orang tuanya. Pemberdayaan masyarakat pada tiap-tiap komunitas adalah bersifat unik atau berbeda antar satu komunitas dengan yang lainnya, untuk itu indikator pemberdayaan masyarakat yang digunakan juga harus menyesuaikan dengan karakteristik komunitas itu dan karakteristik program yang dijalankan. Untuk itu perlu dilakukan kajian lebih lanjut mengenai indikator pemberdayaan masyarakat khusus untuk kasus-kasus tertentu dan indikatorindikator umum untuk semua program pemberdayaan.

Masyarakat dalam hal ini pihak panti asuhan selaku pelaksana program pemberdayaan belum sepenuhnya mempunyai keberdayaan dan tingkat kemandirian yang cukup untuk mengelola pembangunan dalam komunitasnya, untuk itu peran dan keberadaan fasilitator pendamping masih diperlukan dan harus tetap dipertahankan sampai masyarakat benar-benar terbiasa dengan proses-proses pemberdayaan yang dijalankan serta telah menjadi budaya bagi masyarakat tersebut.

Perlu dirintis jalinan kerjasama secara langsung antara komunitas dengan unsur perguruan tinggi, dimana melalui kerjasama tersebut perguruan tinggi dapat menjalankan misinya untuk pengabdian masyarakat dan masyarakat bisa mendapatkan keuntungannya dengan adanya bantuan pemikiran mengenai komunitasnya. Perlu dirintis pula jaringan kerjasama secara langsung antara komunitas dengan pihak swasta atau dunia usaha, dimana melalui kerjasama tersebut masyarakat, khususnya panti asuhan dapat memperoleh manfaatnya dari bantuan baik berupa material maupun finansial, dan pihak swasta bisa menjalankan misinya kepada masyarakat sebagai satu bagian dari tanggungjawab sosial perusahaan (CSR).

\section{Bibliogrphy}

Anggraeni, H.T, \&. (2014). Pembentukan kepribadian muslim di yayasan sosial panti asuhan putrid Darul Hadlonah Purwokerto. Naskah publikasi Pendidikan Agama. Islam IAIN Purwokerto.

Beck, A. T. (1964). Thinking and depression: II. theory and theraphy. Archives of General Psychiatry, 10. 
Dahlia, C. \&. (2010). Brainoloy introduction. Retrieved from https://www.mindsetworks.com/websitemedia/brainology_introduction.pdf

Della. (2012). Cognitive Behavior Therapy untuk Meningkatkan Self Esteem pada Mahasiswa Universitas Indonesia yang mengalami Distres Psikologis. Naskah Publikasi. FPSIKO UI.

Departemen Sosial. (2016). Depsos:Pengertian panti asuhan.

Erwina, I. (2010). Pengaruh cognitive behavior theraphy terhadap post-traumatic stress disorder pada penduduk pasca gempa di kelurahan air tawar barat kecamatan Padang Utara provinsi Sumatera Barat. Universitas Indonesia.

Fauziah. (2009). Pengaruh terapi perilaku kognitif (TPK) pada klien skizoprenia dengan perilaku kekerasan di rumah sakit Marzoeki mahdi Bogor. Universitas Indonesia.

Hartanti, Y. (2008). Pengaruh Mindset terhadap Hasil Belajar Kimia Siswa Kelas XI IPA Madrasah Aliyah Negeri 1 Semarang.

Harvey, J. H. and M. (2006). Workplace bullying: a cross-level assessment. Management Decision, 44(No 9). https://doi.org/DOI 10.1108/00251740610707695

Iswara, R.W. (2013). Penerapan Konseling Kognitif Perilaku untuk Meningkatkan Kemampuan Penyesuaian Diri pada siswa Kelas X SMA Negeri 1 Patianrowo. Jurnal BK UNESA, 6(3).

J, A Cully \& Teten, A. . (2008). A Therapist's guide to brief cognitive behavioral therapy. Retrieved from https://www.mirecc.va.gov/visn16/docs/therapists_guide_to_brief_cbtmanual .pdf

Lodge, J. \& E. F. (2007). Cyber-Bullying in Australian Schools: Profiles of Adolescent Coping and Insights for School Practitioners. Australian Educational and Developmental Psychologist, 24(1):45-5.

Mafriana, S. \&. (2005). Kaji tindak penanggulangan kekerasan dalam rumah tangga. Yogyakarta: Pusat Studi Kependudukan dan Kebijakan Universitas Gadjah Mada.

Martin, P. . (2010). CBT. Retrieved from http://www.minddisorders.com/BrDel/Cognitive-behavioral-therapy.html

Matson, J. L. \& T. H. O. (1988). Enhancing Children's Social Skill: Assessment and Training. New York: Pergamon Press.

Miles, M.B. dan Huberman, A. . (1992). Analisis Data Kualitatif. Jakarta: UI Press.

Mirza, Rina., W. S. (2013). BEHAVIORAL THERAPY UNTUK MENINGKATKAN REGULASI EMOSI PADA ANAK KORBAN KONFLIK ACEH. Journal Psikologia, 8(No 2). $\quad$ Retrieved from https://www.google.com/search?safe=strict\&source=hp\&ei=n15aXfWSGpeav QSkm5qYAQ\&q=+Rina+Mirza\%2C+Wiwiek+Sulistyaningsih+\&oq=+Rina+Mirz a\%2C+Wiwiek+Sulistyaningsih+\&gs_l=psy-

ab.3...1862.1862..3214...0.0..0.157.303.0j2.....0....2j1..gws-

wiz.WuUZjVXvV4M\&ved=0a

Muchti. (2000). Pandangan Umum Mengenai Penyesuaian Diri dan Kesehatan Mental serta Teori-teori terkait. Retrieved from http://library.gunadarma.ac.id/go.php

Maryati, N. (2015). Pengaruh terapi kognitif perilaku terhadap perilaku asertif pada remaja. Naskah Publikasi Prodi Psikologi Fakultas Ilmu Sosial dan Humaniora UIN Sunan Kalijaga.

N, R. (2015). Penyesuaian diri pada remaja yang tinggal di panti asuhan (studi kasus pada remaj yang tinggal dip anti asuhan yatim piatu Muhammadiyah Kalten). In Naskah Publikasi: Fakultas Psikologi Universitas Muhammadiyah. Surakarta.

NACBT. (2007). Cognitive-Behavioral Therapy.

Nevid, J. S., Rathus, S. A., \& Greene, B. (2003). Psikologi Abnormal. (E. K. J. 1 
(terjemahan), Ed.). Jakarta: Erlangga.

Nurodin. (2017). Pendekatan Cognitive Behavioran Therapy (CBT) dalam Mereduksi Kecemasan Menghadapi Dunia Kerja Penyandang Tunadaksa. Naskah Publikasi Bimbingan Konseling Islam. UIN Sunana Kalijaga. Yogyakarta.

Oemarjoedi, A. K. (2003). Pendekatan Cognitive Behavior dalam Psikoterapi.

Ollendick., C. and T. H. (2001). No Title. Annual Review of Psychology, 52.

Sasmita, H. (2007). Efektifitas Cognitive Behavioral Therapy (CBT) pada Klien Harga Diri Rendah di RS Dr. Marzoeki Mahdi Bogor. UI.

Seligman, M. E. P. (2004). Authentic Happiness: Using the New Positive Psychology to Realize Your Potential for Lasting Fulfillment. New York: Simon \& Schuster.

Setyaningsih, F. D. (2013). Peran panti sosial Petirahan Anak (PSPA) Satria Baturaden dalam pembentukan kepribadian anak. Naskah Publikasi Under Graduates.

Shoshani, A., Steinmetz, S., \& dan Kanat-Maymon, Y. (2016). Effects of the Maytiv Positive Psychology School Programon Early Adolescents'. Wellbeing, Engagement, and Achievement. Journal of School Psychology. Retrieved from http://dx.doi.org/10.1016/j.jsp.2016.05.003

Smith, P. K., D. Pepler, and K. R. (2004). Bullying in Schools. How Successful Can Interventions Be? Cambridge: Cambridge University Press.

Srinivasan, B. (2011). Application of Kolb's Experiential Learning Theory to Teaching Architectural Design Principles. Design Principle and Practices, 5. https://doi.org/10.18848/1833-1874/CGP/v05i03/38075\}

Stallard, P. (2002). Cognitive behaviour therapy with children and young people. Journal Behavioural and Cognitive Psychotherapy, 30(3).

Suratmi, M. (2008). Hubungan peran pengasuh dan keterpenuhan kebutuhan pada aspek-aspek perkembangan pribadi yang integral anak-anak asuh di Panti Asuhan El-Jireh Yogyakarta.

Townsend, M. C, 2009. (2009). Psychiatric Mental Healt Nursing: Concepts of Care in Evidence-BasedPractice (6th ed.) (6th ed.). Philadelphia: F.A. Davis.

Wahyuni, S. E., Keliat, B. A., Y. (2010). h cognitive behavior therapy terhadap halusinasi pasien di rumah sakit jiwa pem.propinsi medan. Universitas Indonesia. 